less damage than is normally caused by the conventional viner. In referring to this 'pea sheller' the report states: "The effect on the quality of frozen peas was strikingly demonstrated by inviting the visitors to compare the taste of peas frozen after preparation by the two methods. The effect on canned peas is equally dramatic". Other exhibits included the spin cooker which is particularly suitable for heat-sensitive products due to the shortening of the processing time, and a recently installed belt-trough drier capable of drying foods at a very rapid rate. Expenditure by the Division of Food Preservation in 1962-63 amounted to $£ 422,100$, of which 94 per cent came from the Commonweelth Treasury.

\section{Rounding Errors in Algebraic Processes}

The National Physical Laboratory Notes on Applied Science series has already provided an admirable epitome of modern computing methods (No. 16. Second edition. 1961). A new volume, entitled Rounding Errors in Algebraic Processes, will be equally valuable though of more limited appeal (No. 32. Pp. vi+161. London: H.M.S.O., 1963. 21s. net). The rapid performance by high-speed digital computers of a multitude of arithmetical operations increases the need for a study of the cumulative effect of rounding-off errors beyond the somewhat casual investigations of those who occasionally uso a desk computer. Dr. J. H. Wilkinson gives a systematic analysis of rounding errors in fixed-point and floating-point computations, and a selective but extensive discussion of certain basic problems: zeros of a polynomial, solution of sets of linear equations, inversion of matrices, eigenvalues of a matrix. Although primarily a monograph for the specialist, the book provides an insight into some of the technical problems of a rapidly expanding domain likely to interest anyone concerned with the theory of modern computation.

\section{Uranium Deposits of Blind River}

TeN years have passed since the first diamond drilling was undertaken to assess the economic potentiality of the uranium-bearing conglomerates in the Blind River district of Ontario, and this decade has seen the population of the new mining field rise rapidly to close on 30,000 in 1960 , followed by an equally rapid fall to around 8,000 in 1961-63 as the world glut of uranium ores became recognized and many mines closed down. To-day, the field remains the third most important source of uranium to the Western World, surpassed only by the Colorado Plateau and adjoining regions and by the Witwatersrand; and a special interest therefore attaches to the first full account of its geology, recently published by the Geological Survey of Canada (Bulletin No. 83: Stratigraphy, Petrology, and Genesis of the Elliot Group, Blind River, Ontario, including the Uraniferous Conglomerate. By P. J. Pienaar. Pp. $\mathrm{x}+140$. Ottawa: Queen's Printer, 1963. 2 dollars). The new memoir is concerned principally with the sedimentation of the ore-bearing conglomerates and associated strata, and the much-debated problems of the origin of the ore doposits are not discussed; but it provides extensive sedimentological and chemical information which will help to promote a fuller understanding of the genesis of the mineralization. Both the alluvial and hydrothermal schools of thought will find support for their views, the former in the close association of uranium with sedimentary structures and the latter in the high concentration of the ores--seams of black uranium minerals in some cross-beds are up to an inch thick and carry as much as 40 per cent $\mathrm{U}_{3} \mathrm{O}_{8}$. As in the comparable deposits of the Witwatersrand and Krivoi Rog (Ukraine), the mineralized sediments have been found to be a groat deal older than was originally surmised. Geochronological investigations have lately dated two diabase dykes cutting the Lorrain formation, much higher in the Proterozoic sequence than the Elliot Group conglomerates, respec- tively at 1,600 and 1,995 million years (Geological Survey of Canada Paper 63-17: Age Determination and Geological Studies (Including Isotopic Ages)-4. By G. B. Leech, J. A. Lowdon, C. H. Stockwell and R. K. Wanless. Pp. iv +140 . Ottawa: Queen's Printer, 1963. 75 cents).

\section{Wellcome-Swedish Travelling Research Fellowships, 1964-65}

Applications are invited for the Wellcome-Swedish travelling research fellowships, $1964-65$, the object of which is to encourage co-operation, on an exchange basis, between Swedish and British research workers in any branch of the natural seiences which has a bearing on human and animal medicine. One fellowship is awarded annually to a candidate from the United Kingdom for a year's work in Sweden and one annually to a Swedish eandidate for a year's work in the United Kingdom. The stipend may range from $£ 1,000$ to $£ 2,000$ per annum (or the equivalent sums in Swedish kroner), travelling and some additional expenses being provided in addition. Further information can be cbtained from the Scientific Secretary, the Wellcome Trust, 52 Queen Anne Street, London, W.I. Applications must be submitted before April 30 .

\section{Announcements}

Prof. Erwin Chargaff, professor of biochemistry, Columbia University, has been awarded the first Dr. H. P. Heineken Prize (Df. 35,000) by the Royal Netherlands Academy of Sciences for his work in biochemistry.

Prof. C. L. Pekeris, head of the Department of Applied Mathematics at the Weizmann Institute of Science, Rehovoth, has been elected an Associate of the Royal Astronomical Society of Great Britain. Prof. Pekeris has headed the Department of Applied Mathematics at the Weizmann Institute since 1948. During 1932-35 he was a member of Harvard Observatory, where he earried out research on stellar atmospheres. In 1936, Prof. Pekeris developed the resonance theory of atmospheric tides, and predicted that the temperature rises with height above $35 \mathrm{~km}$. This prediction was later confirmed by rocket soundings.

A conference on "Quality is Good Business", sponsored by the National Council for Quality and Reliability, will be held at Solihull on April 29. Further information can be obtained from the Secretary, National Council for Quality and Reliability, Vintry House, Queen Street Place, London, E.C.4.

THE third symposium on "Enzymes in Clinical Chemistry", organized by the Belgian Society of Clinical Chemistry, will be held in the University of Ghent during April 24-25. Subjects under discussion will include: methodology; isoenzymes; enzymatic histochemistry; congenital enzymopathology. Further information can be obtained from the secretary of the organizing com. mittee, Dr. P. de Moerloose, St.-Jansvest 12, Ghent.

Erratum. The article "Biosynthesis of Messenger and Ribosomal Ribonucleic Acids in the Nucleolochromosomal Apparatus of Animal Cells", which appears on p. 1291 of the December 28 issue of Nature, was submitted by G. P. Georgiev, O. P. Samarina, M. I. Lerman and M. N. Smirnov from the A. N. Severtzov Institute of Animal Morphology, Institute of Radiation and Physico-Chemical Biology, Academy of Sciences and Institute of Biological and Medical Chemistry, Academy of Medical Sciences. Moscow, U.S.S.R. The following corrections should be made: in the legend to Table 1 , references 6 and 7 should be substituted for 8 and 9 , and $\mu \mathrm{c}$. for $\mu \mathrm{g}$; in the lower right-hand graph of Fig. 1, D-RNA should be substituted for R-RNA; reference 15 should read "Lerman, M. I. Mantieva, V. L., and Georgiev, G. P., Dokl. Akad. Nauk U.S.S.R., 152, 744 (1963)"'. 